J. Asiat. Soc. Bangladesh, Sci. 38(1): 93-98, June 2012

\title{
GASTROINTESTINAL HELMINTHS IN PIGEON COLUMBA LIVIA (GMELIN, 1789)
}

\author{
A. BEGUM* AND S. SEHRIN \\ Department of Zoology, Faculty of Biological Sciences, \\ University of Dhaka, Dhaka-1000, Dhaka, Bangladesh
}

\begin{abstract}
A total of 60 pigeon, Columba livia (25 males and 35 females) were examined to observe helminth parasite infection. All the birds were found to be infected by eleven species of helminth parasites: four species of trematoda: Echinostoma revolutum (15\%) E. trivolvus (5\%), Patagifer bilobus (5\%), Ehinoparyphium recurvatum (8.33\%); six species of cestoda: Hymenolepis columbae (63.33\%), Raillietina echinobothrida (100\%), R. bonini (43.33\%), R. cesticillus (100\%), Cotugnia celebesensis (68.33\%), C. cuneata (100\%); and one species of nematoda: Ascaridia columbae (28.33\%). Females showed slightly higher intensity of infestation than the males. Trematode parasites were found in intestine and rectum, cestode parasites were found in duodenum and intestine, nematode parasite Ascaridia columbae was found in caeca. Oesophagus, crop, proventriculus, gizzard, gallbladder, liver, kidney and muscles were free of parasites. Considering among seasons highest intensity of infection was found in autumn.
\end{abstract}

Key words: Helminth parasites, pigeon, prevalence, intensity, season.

\section{Introduction}

Pigeons (Columba livia) are among poultry species kept in the Bangladesh where they are a part of subsistence farming done by most poor families. However, little is known about their socio-economic importance, management and health aspects. Due to perceived little importance of pigeon little attention in term of research has been directed towards the species in Bangladesh. However, in many parts of the country pigeons are seen daily scavenging for food together with other poultry species. It's interaction with man and other domestic and wild birds, portends it as a potential carrier of zoonotic parasites.

The prevalence and intensity of parasitic infestations may be influenced by a number of epidemiological factors including host factors such as age, sex and breed and environmental factors such as climatic conditions (Nadeem et al. 2007). Investigations on chickens and ducks managed under similar conditions like pigeons have shown higher prevalence of gastrointestinal helminths (Muhairwa et al. 2007) which impair productivity and health of these birds.

As helminth parasites of poultry cause a great economic loss to poultry in Bangladesh, therefore, the present study has been designed to investigate the occurrence, prevalence, intensity, organal distribution and seasonal infestation of helminth parasites of pigeon.

* Corresponding author : E-mail: aleya2000@ hotmail.com 


\section{Materials and Methods}

A total of 60 pigeon (25 males and 35 females) were randomly collected from February 2010 to January 2011. The pigeons were examined at the parasitology laboratory of Zoology Department, Dhaka University. The separated parts of the alimentary canal of the pigeons were taken in $0.85 \%$ normal saline solution to collect helminth parasites. Binocular dissecting microscope was used to detect and collect parasites. The trematode, cestode and nematode parasites were fixed with AFA solution and preserved in $70 \%$ alcohol. Before preparing permanent slides the parasites were removed from alcohol and cleaned in lactophenol. A suggestive method was used for the fixing, clearing and staining of the worms (Cable 1963). The collected helminths were identified according to Yamaguti (1958, 1959 and1961).

Prevalence of individual parasite species was calculated as a percentage of the host population that was infested with a specific parasite at a point in time (Thrusfield 1995). Intensity was calculated as number of parasites per infected birds.

\section{Results and Discussion}

Of the 60 pigeons examined, all the birds were found to be infested by helminth parasites (Table 1). Eleven species of helminth parasites were identified, of which four species of trematoda were Echinostoma revolutum 21 (15\%), E. trivolvus 8 (5\%), Patagifer bilobus 11 (5\%), Ehinoparyphium recurvatum 17 (8.33\%); six species of cestoda were Hymenolepis columbae 185 (63.33\%), Raillietina echinobothrida 244 (100\%), R. bonini 121 (43.33\%), R. cesticillus 139 (100\%), Cotugnia celebesensis 177 (68.33\%), C. cuneata 213 (100\%) and one species of nematode was Ascaridia columbae 49 (28.00\%). According to Radfar et al. (2011), the prevalence of helminth Ascaridia colombae, Cotugnia digonopora, $R$. magninumida and $R$. achinobothridia were 16.66, 13.79, 18.62,

Table 1. Prevalence and intensity of helminth infections in C. livia. $(\mathbf{n}=60)$.

\begin{tabular}{lcccc}
\hline Name of the parasites & $\begin{array}{c}\text { No. of host } \\
\text { infected }\end{array}$ & $\begin{array}{c}\text { Prevalence } \\
(\%)\end{array}$ & $\begin{array}{c}\text { total no. of } \\
\text { parasites collected }\end{array}$ & $\begin{array}{c}\text { Intensity } \\
\pm \text { SD }\end{array}$ \\
\hline Trematoda & 09 & 15.00 & 21 & $2.33 \pm 0.032$ \\
$\quad$ Echinostoma revolutum & 03 & 5.00 & 08 & $2.67 \pm 0.298$ \\
$\quad$ E. trivolvus & 03 & 5.00 & 11 & $3.67 \pm 0.049$ \\
$\quad$ Patagifer bilobus & 05 & 8.33 & 17 & $3.40 \pm 0.035$ \\
$\quad$ Ehinoparyphium recurvatum & 38 & 63.33 & 185 & $4.87 \pm 0.061$ \\
Cestoda & 60 & 100.00 & 244 & $4.07 \pm 0.056$ \\
$\quad$ Hymenolepis columbae & 26 & 43.33 & 121 & $4.65 \pm 0.027$ \\
$\quad$ Raillietina echinobothrida & 60 & 100.00 & 139 & $2.32 \pm 0.029$ \\
R. bonini & 41 & 68.33 & 177 & $4.32 \pm 0.029$ \\
R. cesticillus & 60 & 100.00 & 213 & $3.85 \pm 0.045$ \\
$\quad$ Cotugnia celebesensis & 17 & 28.00 & 49 & $2.88 \pm 0.065$ \\
$\quad$ C. cuneata & & & &
\end{tabular}


$32.35 \%$, respectively. Natala et al. (2009) also reported that Raillietina tetragona (4.9\%), $R$. cesticillus (3.0\%), R. echinobothrida (7.6\%), Ascaridia columbae (1.2\%), A. galli $(1.2 \%)$ and Cappillaria anatis $(0.8 \%)$. The values found in the present study of helminth infestation were significantly higher than those of helminth infestation of pigeon observed by Radfar et al. (2011) and Natala et al. (2009). So far, information on the helminth parasites of Columba livia is scanty in Bangladesh, except that of Begum et al. (2008) who observed epidemiology and pathology of protozoan parasites in Trichomonas gallinae in the common pigeon (Columba livia). The present study thus provides baseline or preliminary information on the subject. Almost all the birds were found to be infested with different types of endoparasites throughout the year and each bird was found to harbour more than one type of endoparasites. The overall prevalence of endoparasites on pigeons in the present study appears to be high. Msoffe et al. (2010) in Tanzania also found high prevalence $(79.5 \%)$ of helminth infection. The overall prevalence of various parasites differs greatly among the previous reports as well as when compared with present observation. Diversity of bird endoparasite assemblages may be related many factors, which may include home range, behaviour, size and roosting habit of the host. This may also be attributed to difference in the geographical areas and period of study.

Table 2. Organwise distribution of helminth parasites in $C$. livia. $(\mathrm{n}=60)$.

\begin{tabular}{lccccc}
\hline \multicolumn{1}{c}{ Name of the parasites } & Duodenum & Intestine & Caecum & Rectum & $\begin{array}{c}\text { Total no. } \\
\text { of parasite }\end{array}$ \\
\hline Echinostoma revolutum & - & $3(14.29 \%)$ & - & $18(85.71 \%)$ & 21 \\
E. trivolvus & - & $1(12.5 \%)$ & - & $7(87.5 \%)$ & 8 \\
Patagifer bilobus & - & $4(36.36 \%)$ & - & $7(63.64 \%)$ & 11 \\
Ehinoparyphium recurvatum & - & $2(11.765)$ & - & $15(88.24 \%)$ & 17 \\
Hymenolepis columbae & $91(49.19 \%)$ & $94(50.81 \%)$ & - & - & 185 \\
Raillietina echinobothrida & $184(75.41 \%)$ & $60(24.59 \%)$ & - & - & 244 \\
R. bonini & $69(57.02 \%)$ & $52(42.98 \%)$ & - & - & 121 \\
R. cesticillus & $52(37.41 \%)$ & $87(62.59 \%)$ & - & - & 139 \\
Cotugnia celebesensis & $89(50.28 \%)$ & $88(49.72 \%)$ & - & - & 177 \\
C. cuneata & $104(48.83 \%)$ & $109(51.18 \%)$ & - & - & 213 \\
Ascaridia columbae & - & - & $49(100 \%)$ & - & 49 \\
\hline $\begin{array}{l}\text { Total no. of parasites } \\
\text { (\% of parasites in different }\end{array}$ & $(49.70)$ & $(42.19)$ & $(4.14)$ & $(3.97)$ & 1185 \\
organ) & 589 & & & \\
\hline
\end{tabular}

The helminth parasites were removed from different parts of the alimentary canal. Maximum infestation was found in duodenum. The rate of helminth infection in duodenum was $49.70 \%$, in intestine it was $42.19 \%$. Rectum was found to be less infected than the other organs (Table 2). Parasites of vertebrate hosts feed either on the digested contents of the host in the alimentary canal or the hosts own tissues. The duodenum and intestine seems to be a preferable site for helminth parasites (Marcov 1946). The 
abundance of trematode and cestode parasites in the intestine may be related to their feeding behaviour as they are partially or completely devoid of digestive system. Hence, they absorb the simplest form of nutrients through the cuticle.

The results presented in Table 3 show that the overall prevalence of infestation was $100 \%$ in both sexes and the intensity of females was higher (20.09) than the males (19.28). The male and female birds had eleven endoparasite species each. Raillietina echinobothrida, R. cesticillus and Cotugnia cuneata showed $100 \%$ prevalence both in male and female birds. Highest intensity of infection (5.77) was found in C. celebesensis male and 4.46 was in Hymenolepis columbae female pigeon. Differences between the overall intensity of male and female hosts were very poor, so with this study, it has been proved that gender is not important in helminth infections in pigeon. It was found that the infection rates of male and female were very close to each other, which was statistically insignificant $(\mathrm{P}>0.05)$. Senlik et al. (2005) reported that the gender was not important factor for helminth infections in pigeons.

Table 3. Prevalence of endoparasites according to sex in $C$. livia. (Female $(\mathrm{F})=35$; Male (M) =25)

\begin{tabular}{|c|c|c|c|c|c|c|c|c|}
\hline & \multicolumn{2}{|c|}{$\begin{array}{l}\text { No. of } \\
\text { birds } \\
\text { infested }\end{array}$} & \multicolumn{2}{|c|}{$\begin{array}{c}\text { Prevalence } \\
(\%)\end{array}$} & \multicolumn{2}{|c|}{$\begin{array}{c}\text { Total no.of } \\
\text { endoparasites } \\
\text { recovered }\end{array}$} & \multicolumn{2}{|c|}{ Mean intensity $( \pm$ SD) } \\
\hline & $\mathrm{M}$ & $\mathrm{F}$ & $\mathrm{M}$ & $\mathrm{F}$ & $\mathrm{M}$ & $\mathrm{F}$ & $\mathrm{M}$ & $\mathrm{F}$ \\
\hline Echinostoma revolutum & 3 & 6 & 12 & 17.14 & 8 & 13 & $\begin{array}{l}2.66 \pm \\
0.097\end{array}$ & $\begin{array}{l}2.16 \pm \\
0.052\end{array}$ \\
\hline E. trivolvus & 1 & 2 & 4 & 5.71 & 3 & 5 & $\begin{array}{l}3.00 \pm \\
0.025\end{array}$ & $\begin{array}{l}2.50 \pm \\
0.082\end{array}$ \\
\hline Patagifer bilobus & 3 & 0 & 12 & 0 & 11 & 0 & $\begin{array}{l}3.66 \pm \\
0.048\end{array}$ & 0 \\
\hline $\begin{array}{l}\text { Ehinoparyphium } \\
\text { recurvatum }\end{array}$ & 0 & 5 & 0 & 14.29 & 0 & 17 & $\begin{array}{l}0.00 \pm \\
0.00\end{array}$ & $\begin{array}{l}3.40 \pm \\
0.036\end{array}$ \\
\hline Hymenolepis columbae & 18 & 24 & 72 & 68.57 & 78 & 107 & $\begin{array}{l}4.33 \pm \\
0.097\end{array}$ & $\begin{array}{l}4.46 \pm \\
0.099\end{array}$ \\
\hline Raillietina echinobothrida & 25 & 35 & 100 & 100 & 93 & 151 & $\begin{array}{l}3.72 \pm \\
0.052\end{array}$ & $\begin{array}{l}4.31 \pm \\
0.071\end{array}$ \\
\hline R. bonini & 11 & 17 & 44 & 48.57 & 52 & 69 & $\begin{array}{l}4.73 \pm \\
0.094\end{array}$ & $\begin{array}{l}4.06 \pm \\
0.062\end{array}$ \\
\hline R. cesticillus & 25 & 35 & 100 & 100 & 56 & 83 & $\begin{array}{l}2.24 \pm \\
0.067\end{array}$ & $\begin{array}{l}2.37 \pm \\
0.076\end{array}$ \\
\hline Cotugnia celebesensis & 13 & 28 & 52 & 80 & 75 & 102 & $\begin{array}{l}5.77 \pm \\
0.008\end{array}$ & $\begin{array}{l}3.64 \pm \\
0.046\end{array}$ \\
\hline C. cuneata & 25 & 35 & 100 & 100 & 90 & 123 & $\begin{array}{l}3.96 \pm \\
0.052\end{array}$ & $\begin{array}{l}3.51 \pm \\
0.045\end{array}$ \\
\hline Ascaridia columbae & 7 & 11 & 28 & 31.43 & 16 & 33 & $\begin{array}{l}2.29 \pm \\
0.068\end{array}$ & $\begin{array}{l}3.00 \pm \\
0.027 \\
\end{array}$ \\
\hline
\end{tabular}




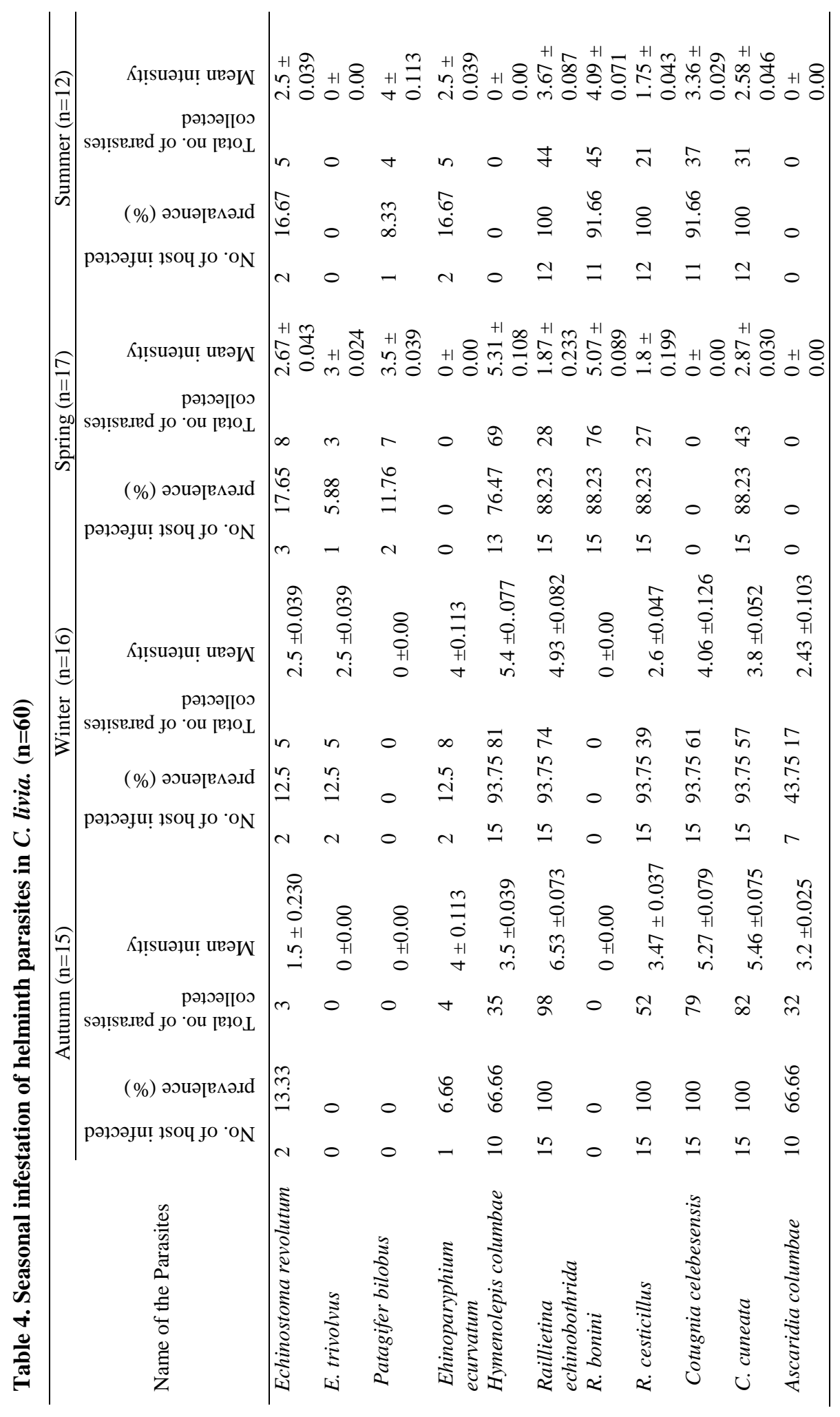


R. echinobothrida, R. cesticillus and C. cuneata have $100 \%$ prevalence in autumn. $P$. bilobus and $R$. bonini showed the lowest prevalence, it was absent in autumn and winter but the prevalence of $R$. bonini in summer was $91.66 \%$ and in spring it was $88.23 \%$ (Table 4). A. columbae was absent in spring and summer. In previous studies (Senlik et al. 2005) helminth infections were more commonly observed during the autumn and winter and abundant rain along with a mild winter create a suitable environment for infestation and the development of helminth eggs. Maximum infection rate in pigeons was seen in October (Sari et al. 2008). In the present study, infections in autumn were highest supporting the finding of Sari et al. (2008) from domestic and mild pigeons of Turkey.

\section{References}

Begum, N., M.A.A. Mamun, S.A. Rahman and A.S.M. Bari, 2008. Epidemiology and pathology of Trichomonas gallinae in the common pigeon (Columba livia). J. Bangladesh Agril. Univ. 6 (2): 301-306.

Cable, R.M. 1963. Illustrated Laboratory Manual of Parasitilogy. Burgess Publ. Co. Miniapolis Minn. 169 pp.

Markov, G.S. 1946. Modes of feeding of parasites Priroda, XII. (Cited form Dogiel, VW 1961). General parasitology, Leningrad Univ. Press (English translation, Z. Kabata) Oliver and Boyd, Edinburg. 516 pp.

Msoffe, P.L.M., A.P. Muhairwa, G.H. Chiwanga and A.A. Kassuku, 2010, A study of ecto- and endo-parasites of domestic pigeons in Morogoro Municipality, Tanzania. African J. Agri. Res. 5 (3): 264-267.

Muhairwa, A.P., P.L.M. Msoffe, S. Ramadhani, E.L. Mollel, M.M.A. Mtambo and A.A. Kassuku, 2007. Presence of gastrointestinal helminthes in free-range ducks in Morogoro Municipality, Tanzania. Livest. Res. Rural Dev. 19 (4): 1-5.

Nadeem, M., M.N. Khan, Z. Iqbal, M.S. Sajid, K. Arshad and M. Yaseen, 2007. Determinants influencing prevalence of louse infestations on layers of district Faisalabad (Pakistan). British Poultry Science. 48 (5): 546-550.

Natala, A.J., N.D. Asemadahun, O.O. Okubanjo, B.M. Ulayi, Y.H. Owolabi, I.D. Jato and K.H. Yusuf, 2009. Survey of Parasites of Domesticated Pigeon (Columba livia domestic) in Zaria, Nigeria. Int. J. Soft Computing. 4 (4): 148-150.

Radfar, M.H., S. Fathi, E.N. Asl, M.M. Dehaghi and H.R. Seghinsara, 2011. A survey of parasites of domestic pigeons (Columba livia domestica) in South Khorasan, Iran, Veterinary Research. 4 (1): 18-23.

Sari, B., B. Karatepe, M.Karatepe and M. Kara, 2008. Parasites of domestic (Columba livia domestica) and wild (Columba livia livia) pigeons in Niğde, Turkey. Bull. Vet. Inst. Pulawy, 52: 551-554.

Senlik, B., E. Gulegen and V. Akyol, 2005. Ectoparasites of domestic pigeons (C. l. domestica) in Bursa Province. Türkiye Parazitoloji Dergisi. 29 (2): 100-102.

Thursfield, M. 1995.Veterinary epidemiology, $2^{\text {nd }}$ edn, Blackwell Scientific, Oxford. $137 \mathrm{pp}$.

Yamaguti, S. 1958. Systema Helminthum. Vol I. The Trematodes of Vertebrates. Interscience Publishers Inc. New York. 979 pp.

Yamaguti, S. 1959. Systema Helminthum. Vol II. The Cestodes of Vertebrates. Interscience Publishers Inc. New York., 860 pp.

Yamaguti, S. 1961. Systema Helminthum. Vol III. The Nematodes of Vertebrates. Interscience Publishers Inc. New York., 679 pp.

(Received revised manuscript on 21 June 2012) 